\title{
Interrelation of Platonic and Jewish-Christian Aspects of the Symbolism of the Cross in the Apocryphal Acts of the Apostles, Church Fathers and Christian Iconography
}

\author{
Irina Kolbutova, $P h D$ \\ St. Thomas Institute, Moscow
}

Irina_Kolbutova@yahoo.co.uk

\section{Summary}

Considering the symbolism of the cross in the Apocryphal Acts of the Apostles, scholars interpreted it in terms of Platonic and Gnostic influences. In this article I made an attempt to demonstrate a more profound ancient mythological and Jewish-Christian mystical background of this symbolism, which can be traced later in Christian Patristic writings and iconographic patterns.

\section{Keywords}

cross - time - eternity - suffering Logos - heavenly Self

\section{Introduction}

In his article "Platons Weltseele und das Kreuz Christi" W. Bousset ${ }^{1}$ attracted a scholarly attention to the treatment of the cross by the early Church Fathers. This scholar noted that Justin Martyr and (implicitly, according to Bousset) Irenaeus explained the cosmic structure of the cross as comparable to the two circles of the world soul placed in the shape of the letter X, described by Plato

1 W. Bousset, "Platons Weltseele und das Kreuz Christi," Zeitschrift für die neutestamentliche Wissenschaft und die Kunde von der älteren Kirche, 14 (1913), pp. 273-285. 
in his Timaeus. Bousset observed that the idea of the cosmic dimension of the cross may correlate with the cross-symbolism elaborated by the authors of the Apocryphal Acts of Peter, Andrew, and John. As J. Bolyki has noted recently, "the cross in the Apocryphal Acts of the Apostles becomes an ordering principle of the universe (cosmos). It takes up the same role as the Logos in John's Prologue. The cross is explicitly called Logos in Acts of Andrew (Mart I.14), Acts of John (98) and Acta Petri (38). It has a role in keeping the created world together (Acts of John 99 and Acts of Andrew Mart I.14). The cross gives structure to the universe."

Other aspects of the symbolism of the cross were discussed by J. Daniélou, according to whom the cross as a Jewish-Christian theological notion has a variety of meanings. It is considered as a cross of glory, signifying the victory of Christ. The cross in the Jewish-Christian tradition is comprehended as a living being, accompanying Christ and sometimes is even identical with Christ. Moreover, the shape of the cross implies its cosmic dimensions, evoking the universality of the Redemption accomplished by Christ and the regeneration of the world, and, as J. Daniélou has remarked, in this function the universal cross acquired the functions of the Logos in the theological system of Philo. ${ }^{3}$

The same connection between the notion of the Logos elaborated by Philo with the concept of Logos in the Apocryphal Acts of John was discussed by P.J. Lalleman, who noted that in this text "the cross also reveals itself as Logos," adding that "in late Manichaeism the cross of light is in principle the same as the suffering Christ ..." ${ }^{\prime 4}$ Furthermore, the same scholar formulated the conception of the suffering in the Acts of John in the following way: "Suffering is man's restless errantry in darkness before the reception of the divine revelation .... From this perspective, the idea that mankind suffers because it lives in chaos and instability appears also in the description of the cross of light. Those who are (as yet) separate from it does not have only one form $(98.2,100.1)$. The stabilizing work of the cross (99.1-3) creates a place of rest (99.7), but the one form will only be restored when men are lifted up (100.2-4). The description of suffering easily shades into that of salvation. To sum up, without proper knowledge of Christ mankind lacks stability and 'one form' ... before salvation takes

2 J. Bolyki, "Head Downwards': The Cross of Peter in the Lights of the Apocryphal Acts, of the New Testament and of the Society-transforming Claim of Early Christianity," in: The Apocryphal Acts of Peter: Magic, Miracles and Gnosticism, ed.J.N Bremmer (Studies in the Apocryphal Acts of the Apostles, 3), Louvain, 1998, p. 116.

3 J. Daniélou, Théologie du judéo-christianisme, Paris, 1991, pp. 327-53.

4 P.J. Lalleman, The Acts ofJohn: a Two-Stage Initiation intoJohannine Gnosticism (Studies in the Apocryphal Acts of the Apostles, 4), Leuven, 1998, pp. 187-188. 
place, chaos reigns, whereas the stabilizing effect of the cross results in harmony."5 Moreover, as P.J. Lalleman noted, "the song and dance of Christ expresses his suffering which is also their suffering. In the song and dance, or rather in Christ himself as a mirror (95.45-46), men see their real identity." ${ }^{6}$

According to Lalleman, the above-mentioned features of the symbolism of the cross in the Acts of John indicate on the fact that it can be placed into the context of the "Gnostic mythology. The fact that the Logos is identified with the cross of light also suggests a resemblance with the idea of the particles of the divine Logos that are spread over the world. A 'collection of members' (100.3-4) occurs in several other Gnostic texts as well in two passages which are attributed to Melito and which are not obviously Gnostic." ${ }^{7}$ However, as we shall make an attempt to demonstrate in this article, the themes and motives discussed by Lalleman as referring to "Gnostic" or Manichaean conceptions can be discerned in the theological implications found in the images, iconographic or described in the ancient texts, and put into a broader cultural and theological context, following the way, indicated by Bousset and Daniélou and taking into consideration the treatment of the cross by the Church Fathers, in whose writings the Jewish and other Semitic mythological conceptions are intricately interlaced with the Hellenistic philosophical notions.

\section{1 \\ The Primordial Chaos and a Salvation of the Mind of the Darkness}

As it was mentioned previously, P.J. Lalleman has made an observation that "before salvation takes place, chaos reigns, whereas the stabilizing effect of the cross results in harmony," ${ }^{8}$ while in the article "Birth Upside Down or Right Side Up?" J.Z. Smith ${ }^{9}$ has attempted to establish a cultural context for the martyrdom of Peter in the apocryphal Acts of Peter where the Apostle is crucified head downwards, characterising the reversal of the cosmic order in the following way: "During the Hellenistic period, there was a "radical revaluation" (Hans Jonas's phrase) of this all-pervasive "cosmological conviction," a revaluation which has led classicists such as Gilbert Murray to speak of a "failure of nerve," E.R. Dodds to describe the period as "an age of anxiety," and Eric Voegelin to formulate a shift from a "compact experience of the cosmos" to a

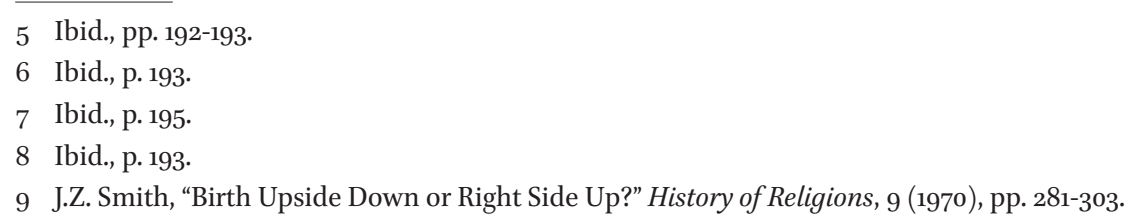


"differentiated experience of existential tension." Hellenistic man suffers from what might be termed cosmic paranoia. He experiences himself to be naked and helpless; he sees danger and threat everywhere. Looking up at the heavens, at the stars, and the motions of the heavenly bodies, he no longer sees the guarantors of order, the guardians of a good cosmic and human destiny, the positive limits placed on the chaotic powers above and below and on the span of human existence; but rather a grim system of aggressors, an openly hostile army which seeks to chain him."10

This comprehension of the universe is presented by Hippolytus in the description of the heresy of the Peratae, in their exegesis of the Scriptural narrative about the Brazen serpent (Book V, chapter XI).

Now, he (the Peratic) says, the stars are the gods of destruction, which impose upon existent things the necessity of alterable generation. These, he says, Moses denominated serpents of the wilderness, which gnaw and utterly ruin those who imagined that they had crossed the Red Sea. To those, then, he says, who of the children of Israel were bitten in the wilderness, Moses exhibited the real and perfect serpent; and they who believed on this serpent were not bitten in the wilderness, that is, (were not assailed) by (evil) powers. No one therefore, he says, is there who is able to save and deliver those that come forth from Egypt, that is, from the body and from this world, unless alone the serpent that is perfect and replete with fulness. Upon this (serpent), he says, he who fixes his hope is not destroyed by the snakes of the wilderness, that is, by the gods of generation. (This statement) is written, he says, in a book of Moses. This serpent, he says, is the power that attended Moses, the rod that was turned into a serpent. The serpents, however, of the magicians - (that is,) the gods of destruction - withstood the power of Moses in Egypt, but the rod of Moses reduced them all to subjection and slew them. This universal serpent is, he says, the wise discourse of Eve. This, he says, is the mystery of Edem, this the river of Edem .... ${ }^{11}$

This kind of interpretation of the brazen serpent can shed light on some rather enigmatic features in the treatment of the cosmic dimensions of the cross made by Justin Martyr, to whose interpretation of the cosmic cross as Plato's world soul go back those of Irenaeus and Gregory of Nyssa, which has been

\footnotetext{
$10 \quad$ Ibid., p. 295.

11 Tr. by J.H. Macmahon, in: Hippolytus, The Refutation of All Heresies, Edinburgh, 1868, pp. 165-166.
} 
indicated by W. Bousset. ${ }^{12}$ The same connection was observed by Armitage Robinson in the note to his translation of the Demonstration of the Apostolic Preaching of Irenaeus. ${ }^{13}$ In his First Apology 6o, where the cross is presented as the logos putting an order on the chaotic forces, Justin wrote:

And the physiological discussion concerning the Son of God in the Timoeus of Plato, where he says, "He placed him crosswise in the universe," he borrowed in like manner from Moses; for in the writings of Moses it is related how at that time, when the Israelites went out of Egypt and were in the wilderness, they fell in with poisonous beasts, both vipers and asps, and every kind of serpent, which slew the people; and that Moses, by the inspiration and influence of God, took brass, and made it into the figure of a cross, and set it in the holy tabernacle, and said to the people, "If ye look to this figure, and believe, ye shall be saved thereby." And when this was done, it is recorded that the serpents died, and it is handed down that the people thus escaped death. Which things Plato reading, and not accurately understanding, and not apprehending that it was the figure of the cross, but taking it to be a placing crosswise, he said that the power next to the first God was placed crosswise in the universe. And as to his speaking of a third, he did this because he read, as we said above, that which was spoken by Moses, "that the Spirit of God moved over the waters." For he gives the second place to the Logos which is with God, who he said was placed crosswise in the universe; and the third place to the Spirit who was said to be borne upon the water, saying, "And the third around the third."14

The transition of the thought of Justin from the cross with the brazen serpent, associated with Plato's conception of the world soul, to the motive of the Spirit moving over the water, at first sight, seems not quite logical or justified. However, taking into consideration the myth of Peratae, where the serpent represents the river of Edem, one may assume that in this passage of Justin the combination of the cosmic cross, the serpent, the Spirit, and the water can be

12 Bousset, "Platons Weltseele" pp. 297-285.

13 St. Irenaeus, The Demonstration of the Apostolic Preaching, tr. from the Armenian with introduction and notes by J. Armitage Robinson, London-New York, 1920, p. 101, n. 3.

14 The Writings of Justin Martyr and Athenagoras, tr. by M. Dods, G. Reith and B.P. Pratten, Edinburgh, 1867 , p. 58. It should be noted that, according to A.J. Droge, "the statement about 'the third' comes not from the Timaeus, as Justin seems to imply, but from the Pseudo-Platonic Second Letter 312e." (A.J. Droge, "Justin Martyr and the Restoration of Philosophy," Church History, 56 (1987), p. 309). 
comprehended againt the background of ancient mythological conceptions, which we shall make at attempt to demonstrate in what follows.

In his book devoted to the baptismal theology of the ancient church P. Lundberg has indicated on the fact that in the Jewish mythological consciousness the waters of Tehom were considered as ambivalent, as source of fertility, and at the same time almost identified with the Sheol and personified as the serpent Leviathan. ${ }^{15}$ Similar mythological motives are present in the Hermetic treatise Poimandres, as it was interpreted by P. Kingsley, who discovered in the presentation of the number of changes, namely, of the light into darkness, turning into a watery, primal chaos, and the fire leaping up out of the darkness, an ancient Egyptian cosmology mirroring the everyday disappearance and reappearance of the sun. In this cosmological conception the darkness represents the primeval form of the light, while this primeval, watery chaos is represented as a coiled serpent as the first stage of divine manifestation in the mythological past and at the same time as "the primordial form of God as he 'devises the Logos, the creative Word which lays down the laws of what is to be made."'16

Similar cosmological conceptions are implied in the baptismal rituals where an important role is played by the cross. As it was established by P. Lundberg, in the baptismal typology of the early Church Christ descending into the waters of Jordan is associated with the sun appearing for illuminating the universe. The Baptism of Christ is compared with the sun descending to the waters of the Ocean, and this theme is also connected with the descent of Christ to the Hell, which joins the feast of the Epiphany with the Easter. According to P. Lundberg, it is quite natural to find a symbolism of the cross in the context of the baptismal typology, since the cross is merged in the water in the ritual of the feast of the Epiphany. ${ }^{17}$

On the other hand, one can trace in these images a re-enactment of the story of the creation of the world, by which the presence of the Spirit and the Logos together with the image of the water can be explained. These motived can also be connected with an Egyptian theme underlying the teaching of the Poimandres, which can be continued by the material discussed by G. Englund in an article devoted to the exposition of the creation of the world in the socalled "Shu theology," where this scholar summarized the process of the creation of the world presented in this ancient Egyptian literary source in the

\footnotetext{
15 P. Lundberg, La typologie baptismale dans l'ancienne église, Uppsala, 1942, pp. 64-70.

16 P. Kingsley, "Poimandres: the Etymology of the Name and the Origin of the Hermetica," Journal of the Warburg and Courtauld Institutes, 56 (1993), pp. 16-17.

17 Lundberg, La typologie baptismale, p. 169-171.
} 
following way: "The name of the primordial inert waters is Nun ... and nothing can be distinguished in that mass. It is only when the eye has found the duality, Shu and Tefnut, that it is possible to be aware of anything. Nun did not, however, see Shu with his face. There are at least two reasons for this. First, Nun is and remains the uncreated, undifferentiated, non-conscious water, secondly Shu comes into being within Nun, within the Water ...."18 Furthermore, "the Shu theology maintains that Shu was exhaled by Atum .... The birth of Shu means that light is dawning,"19 and in the Poimandres a watery chaos exhaled a vapour. One may remark also that "in Sirach 24:3 Wisdom comes forth from the mouth of God and covers the earth like a mist."20

In the Poimandres narrative, a fire leaps out from the moist nature, and an upward movement of the fire is simultaneous with the downward movement of the Logos descending from the Light. The air follows the fire, which seems to be named Pneuma. The air separates the fire from the mixed earth and water, where the earth is not visible under the water. And, evoking the Genesis account, above this water covering the earth is brought a substance called pneumatikos Logos, which is, probably, the result of the union of the Logos descending from the Light-Nous and the fire-pneuma, ascending from the primeval moist substance. This union, is, probably, juxtaposed as a chaotic fiery substance put to order and articulated by the Logos to the inarticulate primordial sound, resembling the voice of the fire, emitted by the watery substance alongside with the exhalation of the vapour. This process of articulation and rationalisation of the chaotic primordial energies can be an echo of the creation of the world by the reiteration of the words by Shu who "listens to the words and then conveys the words to the manifold world by repeating them."21

Another re-interpretation of similar mythological motives, although demonstrating a "radical revaluation" of the "cosmological conviction," can be traced in the Nag Hammadi tractate Paraphrase of Shem. In the beginning of this text an anonymous author asserts: "There was Light and Darkness and

18 G. Englund, "The Eye of the Mind and Religious Experience in the Shu Theology from the Egyptian Middle Kingdom," in: "Being Religious and Living through the Eyes". Studies in Religious Iconography and Iconology. A Celebratory Publication in Honour of J. Bergman, ed. P. Schalk and M. Stausberg, Uppsala, 1998, p. 91.

19 Ibid., p. 93.

20 C.H.T. Fletcher-Louis, "The Cosmology of P and Theological Anthropology in the Wisdom of Jesus ben Sira," in: Of Scribes and Sages: Early Jewish Interpretation and Transmission of Scripture. Volume I: Ancient Versions and Traditions, ed. C.E. Evans (Studies in Scripture in Early Judaism and Christianity, 9; Library of Second Temple Studies, 50) , London, 2004, p. 13 .

21 Englund, "The Eye of the Mind," p. 107. 
there was Spirit between them .... The Light was thought full of hearing and word. They were united into one form. And the Darkness was wind in waters. He possessed the mind wrapped in a chaotic fire."22 In the opinion of F. Wisse, "the first treatise of the Corpus Hermeticum, the Poimandres, is a parallel of particular significance for the understanding of both the framework and the tractate as a whole." ${ }^{33}$ This scholar noted that "Shem tells about an ecstatic experience during which his mind was separated from his body as if in sleep, when he was caught up to the top of creation close to the supreme being, the Light." ${ }^{24}$ The same mystical experience in a deep sleep is described by a recipient of the revelation of the Poimandres.

Furthermore, in the Paraphrase of Shem the Darkness was covered with the water, and in the discussed above "Shu theology" "the eye of Atum plays a decisive role in creation ... eye is the creator of mankind, while Atum is still alone and inert in the primordial waters ..." 25 "When the sole eye has found duality in the undifferentiated oneness and returns to the One God, he has obtained two eyes and the sole eye takes its place on his forehead where he henceforth has his uraeus." ${ }^{26}$ And "the uraeus was regarded as the fire-spitting eye of the sun-god."27 In this way, it becomes comprehensible that this mind of the serpent-darkness is the sun, and the whole visible universe is considered as the realm of evil. The process of the putting into order and making the chaotic fire reasonable by means of the luminous Logos takes place in the Paraphrase of Shem like in the Poimandres, but in the Paraphrase of Shem it is re-comprehended as the salvation of the mind of the Darkness.

This conception of the salvation of the mind can be echoed in the writings of Gregory of Nyssa who in the I Homily on the Resurrection described the descent of Christ to Hades as the salvation of the mind in the heart of the earth and in the same I Homily of Gregory the triple order of the victory over evil is described, corresponding to three days of the descent of Christ into the hell.

22 Tr. by F. Wisse, in: The Nag Hammadi Library in English, ed. J.M. Robinson, Leiden, 1996, p. 342.

23 F. Wisse, "The Redeemer Figure in the Paraphrase of Shem," Novum Testamentum, 12 (1970), p. 131.

24 Ibid., p. 130.

25 Englund, "The Eye of the Mind," p. 90.

26 Ibid., p. 96.

27 M. Lurker, The Gods and Symbols of Ancient Egypt (An illustrated dictionary), London, 1996, p. 48. See also on this subject: R. Anthes, "Mythology in Ancient Egypt," in: Mythologies of the Ancient World, ed. S.N. Kramer, Chicago, 1961, p. 15-92. 
... in three days the essential evil is ejected, from men, from women, and from the genus of the snakes, in which the nature of evil first appeared."28

Furthermore, in the Paraphrase of Shem the revealer asserts:

It is I who opened the eternal gates which were shut from the beginning. To those who long for the best of life, and those who are worthy of the repose, he revealed them. I granted perception to those who perceive. ${ }^{29}$

And this idea, probably, goes back to an Egyptian mythological conception: "The birth of Shu means that light is dawning and this makes those who are in the doorway, probably, the doorway of the horizon, rejoice."30 Again, one may remark that in the interpretation of Gregory of Nyssa in the 12th Homily on the Song of Songs the baptism means the unfoldment of our veil $(\varkappa \alpha \tau \alpha \pi \varepsilon \tau \tau \sigma \mu \alpha)$ of the flesh, by the mortification of our earthly members, by which the door is open which allows the Logos enter the soul, about which J. Daniélou noted that the image of the veil $(\kappa \alpha \tau \alpha \pi \varepsilon \dot{\tau} \tau \sigma \mu \alpha)$ refers to the curtain of the temple concealing the Holy of Holies, and which is associated with the Body of Christ in the Hebrews Epistle. ${ }^{31}$

This way of comprehension of the meaning of the ritual of baptism by Gregory of Nyssa, probably, can correspond to the ancient baptismal rituals and their interpretations discussed previously, which can be added to the material adduced by J. Daniélou in his discussion of the Jewish-Christian background of the symbolism of the cross formulated by Gregory of Nyssa in his writings, including the I Homily on the Resurrection, where this Church Father synthesized the Jewish-Christian and Greek philosophical themes, and among these the notion of the universal Logos encompassing the universe and symbolized by the cosmic cross. ${ }^{32}$

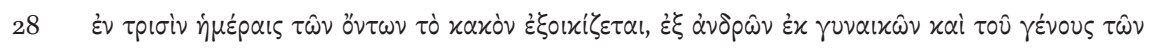

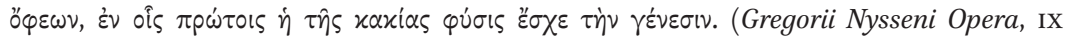
(Sermones, pars I), ed. E. Gebhadt, Leiden, 1967, p. 286,10-12)

29 Tr. by F. Wisse, in: The Nag Hammadi Library, p. 356.

$30 \quad$ Englund, "The Eye of the Mind," p. 93.

31 J. Daniélou, Platonisme et théologie mystique: Essai sur la doctrine spirituelle de Saint Grégoire de Nysse, Paris, 1944, p. 305.

32 J. Daniélou, "La Symbolisme cosmique de la croix," La Maison-Dieu, 75 (1963), pp. 23-36. 
The symbolism of the cross in the context of an ancient comprehension of the baptismal rituals, as it seems, was incorporated into an iconographic meaning of the cross within the framework of the architectural symbolism of the building of a baptistery in the function of a rational principle putting an order on the chaotic watery substance, which we shall make an attempt to demonstrate at what follows.

To begin with, in the Paraphrase of Shem, as it was suggested previously, the mind of the serpent-darkness is, probably, identified with the sun, and the whole visible universe is considered as the realm of evil. As D.M. Parrott has demonstrated, the primordial chaos in the tractate Eugnostos the Blessed, as in the Paraphrase of Shem, may be represented also by an Egyptian divine primordial serpent, ${ }^{33}$ and one can find an exposition of the idea of the structuring the primordial chaos by means of putting on it measure and time.

Now immortal Man revealed aeons and powers and kingdoms and gave authority to everyone who [appeared from] him, to make [whatever they desire] until the days that are above chaos. ${ }^{34}$

Therefore our aeon came to be as the type of Immortal Man. Time came to be as the type of First Begetter, his son. [The year] came to be as the type of [Savior. The] twelve months came to be as the type of the twelve powers. The three hundred and sixty days of the year came to be as the three hundred and sixty powers who appeared from Savior. Their hours and moments came to be as the type of the angels who came from them (the three hundred sixty powers), (and) who are without number. ${ }^{35}$

Similar functions are attributed to the angel Metatron in a Jewish mystical tradition. A. Orlov attracted a scholarly attention to the opinion of G. Stroumsa

33 "Probably, the earliest account is that in which Amun is identified as the primal snake Kematef. Kematef's son, then, who is also a snake (and hence is his father's image) is the direct creator of the Eight .... The four makes among the Eight in the original Part A of Eugnostos, and in Egyptian religion, are given names that indicate their role. In the former case, the names have to do with their current function, namely that of begetting: they are responsible for begetting other divine beings. In the latter, the names have to do, not with the current role, but with their being gods of chaos; thus: Nun, the primal waters; Heh, endless space, Keku, darkness, and Tehemu, the disappearing or the lost." (D.M. Parrott, "Gnosticism and Egyptian Religion," Novum Testamentum, 29 (1987), p. 87).

35 Ibid., p. 234. 
who appealed to reconsider the etymology of Metatron from $\mu \dot{\varepsilon} \tau$ pov and/or metator, ${ }^{36}$ since, according A. Orlov, the "term praemetitor in its hypothetical meaning as a 'measurer' is an important piece of evidence because it is almost phonetically identical with the Slavonic term prometaya .... In ch. 43 of 2 Enoch, immediately after the use of this term, Enoch makes the following statement:

I have arranged the whole year. And from the years I calculated the months, and from the months I calculated the days, and from the day I calculated the hours. I have measured and noted the hours. And I have distinguished every seed on the earth, and every measure and every righteous scale. I have measured and recorded them."37

One may note that the Hermetic Aion similarly governs the world partly by means of necessity, partly by providence, partly by nature, or by some other means ( $\mathrm{CH} \mathrm{XI} 5$ ), and the notion of Aion is mentioned several times by the late antique author John of Gaza (in between fifth and seventh century) in his description of the vault decoration of the winter baths of Gaza or Antioch, adorned by the image of the cross and the cosmic powers, ${ }^{38}$ where Aion is understood normally by the scholars as the personification representing this notion. ${ }^{39}$ D. Levi, assuming such personification to which the text refers, attempted to translate the lines $137 \mathrm{ff}$. in the following way: "And self-sown Aion was represented in blooming splendor leaning toward another running circle of the much-whirled years, the forefather, surrounded by the ever-running roads; he, who, preserving the generation in an intellectually perceptible rotation, and lifting the whirling helm of Harmony, herds the year of twelve months turning it round, and causes one year to discharge itself into another, then

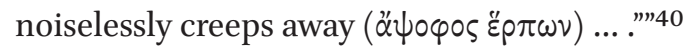

$3^{6}$ A. Orlov, "The Origin of the Name "Metatron" and the Text of 2 (Slavonic Apocalypse of) Enoch," Journal for the Study of the Pseudepigrapha, 21 (2000), pp. $23-24$.

37 Ibid., p. 24.

38 L. Renaut, "La description d'une croix cosmique par Jean de Gaza, poète palestinien du vie siècle," in: Iconographica: Mélanges offert à Piotr Skubiszewski, Poitiers, 1999, p. 213. The text is from the edition of P. Friedländer, Johannes von Gaza und Paulus Silentiatius: Kunstbeschreibungen justininischer Zeit, Leipzig-Berlin, 1912.

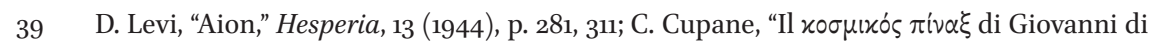
Gaza: una proposta di ricostruzione," Jahrbuch der Österreichischen Byzantinistik, 28 (1979), p. 202.

$40 \quad$ Levi, “Aion," p. 311. 
The characterization of Aion as creeping ( $\left.\tilde{\varepsilon}^{\prime} p \pi \omega \nu\right)$ is used in the Chaldaean Oracles, ${ }^{41}$ and in general the description of Aion in the text of John of Gaza has similar features with a Chaldaean Aion. This deity "“mingles aeon with aeon" and communicates his own movement to the sun. The reason for his identification with the transmundane sun must be sought in the perpetual circular movement of the "fiery God" who, in the noetic sphere, accomplishes revolution after revolution." ${ }^{42}$ These Chaldaen features can also be found in the text of John of Gaza if to consider the verses 19-22:

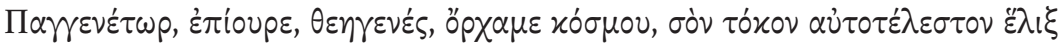

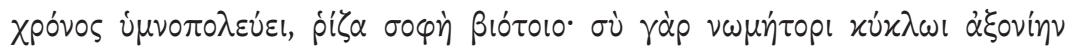

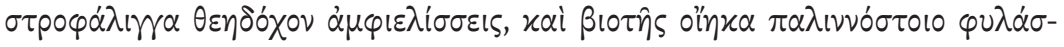
$\sigma \varepsilon i{ }^{43}$ (The generator of all, watcher, born by god, the leader of the universe, aspiralwise time composes a song of praise to your self-accomplished child; a wise root of life; you wind round in a ruling circle a constantly moving god-receiving axle, you guard a helm of government over a recurrent life.)

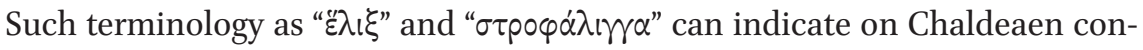
ceptions employed by John of Gaza, since in the Chaldaean doctrine regarding Aion one can encounter such characterizations of this entity as Aion whirling all Sources and Principles around and keeping "them in incessant circular mo-

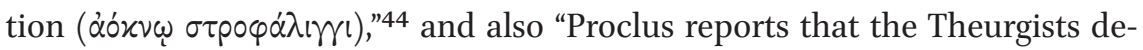
scribed Chronos as "eternal", "infinite", "young and old", "winding spiralwise"

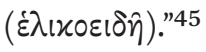

Further John of Gaza associates the notion of the Aion with the shape of the cross in the lines 35-37

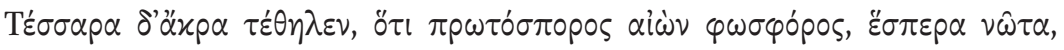

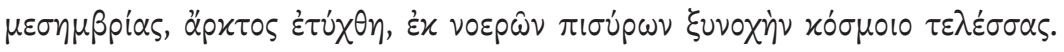
(Four extremities have flourished, since you, a fist-generated, light-bearing aion, have accomplished a control over the intelligible tetrade of the universe, namely, the west, east, south and north.)

\footnotetext{
41 H. Lewy, Chaldaean Oracles and Theurgy, Le Caire, 1956, p. 102, n. 151.

42 Ibid., pp. 151-152.

43 Renaut, "La description d'une croix," p. 213.

44 Lewy, Chaldaean Oracles, p. 99.

45 Ibid., p. 102.
} 
The description of the vault of the baths made by John of Gaza, as L. Renaut ${ }^{46}$ has remarked, has a precise iconographic parallel, namely, the vault decoration of the baptistery in Albenga (late 5 th c.). ${ }^{47}$ On the vault of this baptistery the cross-shaped monogram of Christ is in an innermost circle, and both the circle and the monogram, together with the letters $A$ and $\Omega$, are repeated in two radiating outer circles, with a gradual decrease in the intensity of colour, which can correspond to the verse 41 from the poem of John of Gaza.

Besides, the geometrical construction of the vault decoration of the baptistery in Albenga can be related to some of the images which may be found in the writings of Plotinus, who in IV 3 [27] 17, 12-21 describes the radiating luminous spheres:

For there is a kind of centre, and around this a circle shining out from it,

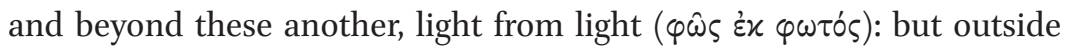
these there is no longer another circle of light but this next circle through lack of its own light needs illumination from another source. Let this be a wheel, or rather a sphere of a kind which from the third - for it borders upon it - obtains all the illumination which that third receives. So the great light abides and shines, and its radiance goes out through the world in rational order and proportion; the other lights join in illuminating, some staying in their places, bur others are more attracted by the brightness of what is illuminated. ${ }^{48}$

Moreover, the monogram of Christ on the vault of the baptistery in Albenga, that is, the letters $\mathrm{X}$ and $\mathrm{P}$, which are shaped as the radiating lines, seem to remind a Plotinian metaphor of the radiating lines is III 7 [45] 3, 15-20.

... seeing all this one sees eternity ( $\left.\alpha i \omega^{\prime} \nu\right)$ in seeing a life that abides in the same, and always has the all present to it, not now this, and then again that, but all things at once, and not now some things, and then again others, but a partless ( $\dot{\alpha} \mu \varepsilon \rho \dot{s} \varsigma)$ completion, as if they were all together in a point, and had not yet begun to go out and flow into lines .... ${ }^{49}$

46 "Seule la mosaïque d'Albenga pourrait, à la rigueur, répondre à un tel symbolisme." (Renaut, "La description d'une croix," pp. 218-219).

47 B. Brenk, Spätantike und frühes Christentum (Propyleän Kunstgeschichte, 15), Frankfurt am Main-Berlin-Vienna, 1985, pl. 20.

48 Tr. by A.H. Armstong in: Plotinus, Ennead IV with an English translation by A.H. Armstrong (Loeb Classical Library, 443), Cambridge, MA-London, 1984, p. 89.

49 Tr. by A.H. Armstong in: Plotinus, Ennead III with an English translation by A.H. Armstrong, third edition (Loeb Classical Library, 442), Cambridge, MA-London, 1993, p. 305. 
This Plotinian metaphor can be identified in the iconographic monogram of Christ as a literal reading of the time (Xpóvos - XP) and eternity ( $\alpha i \omega v$ - A and $\Omega)$. Furthermore, in Plotinus time is brought into existence by a restlessly ac-

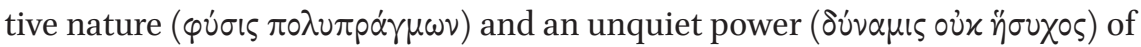
the Soul (III 7 [45] 11, 23-27)

... and, as from a quiet seed the formative principle, unfolding itself, advances, as it thinks, to largeness, but does away with the largeness by division and, instead of keeping its unity in itself, squanders it outside itself and so goes forward to a weaker extension ....50

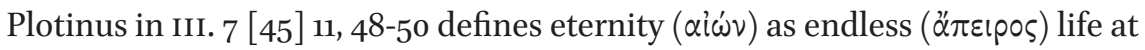
rest while the time as life of the soul in movement:

... then we must say that there is, instead of the life There, another life of this power of the soul, so to say, homonymous to the other life ....51

In this way, Plotinus interprets the meaning of the word " $\alpha i \omega v$ " etymologically, as connected with the idea of life, which was noted by A.J. Festugière, ${ }^{52}$ who based his research on the discoveries made by E. Benveniste. ${ }^{53}$ Moreover, one may take into consideration the connection between the notion of an endless time, represented as a divinity, and the notion of life in the teaching of Pherecydes (whose floruit is put around 544 B.C.). As it was formulated by M. Boyce, "According to his cosmogony, there were three divine beings who had always existed: Chronos or Time, Zas, 'He who liveth' (his name for the highest god), and Chthonie, "She who is beneath the earth'. Zas gave Chthonie earth as a robe of honour, and wedded her as Gē; but Chronos, remaining alone without consort, produced from his own seed fire, wind and water. He was opposed by Ophioneus 'the Snaky One', who had been 'born' (of unknown parents), and who with his armies fought Chronos for possession of heaven. Ophioneus was defeated and thrust down into the ocean; and thereafter Chronos reigned supreme ....."54

$50 \quad$ Ibid., p. 339 .

$51 \quad$ Tr. by A.H. Armstong, modified, in: Plotinus, Ennead III, p. 341.

$5^{2}$ “... de toute manière, 'force de vie' ou 'temps que dure la force de vie', l' $\alpha i \omega$ ' $v$, en son acception première, comporte un lien étroit avec l'idée de vie." (A.J. Festugière, "Le sens philosophique du mot AI NN," in: Études de philosphie grecque, Paris, 1971, p. 271).

53 E. Benveniste, "Expression indo-européenne de l' «éternité»," Bulletin de la Société de linguistique, 38 (1937), pp. 103-112.

54 M. Boyce, A History of Zoroastrianism (Vol 2: Under the Achemenians), Leiden-Köln, 1982, pp. 150-151. 
As M. Boyce has observed, "Babilonian elements have been seen in his teaching about the serpent-god who now inhabits the ocean, and who, though he once fought with Chronos, is not a principle of evil.." ${ }^{\prime 5}$ On the other hand, "a possible remote origin for such a concept has been traced in Egyptian beliefs concerning the sun-god Rē, who in the Book of the Dead, for example, is made to declare: 'I am the oldest of the Primeval Ones, my soul is the soul of the eternal gods; my embodiment is Eternity, my form is Everlasting, the lord of years, the ruler of eternity'" ${ }^{\prime} 6$

One may recall at this point that the primordial chaos in the Eugnostos the Blessed may be represented also by an Egyptian divine primordial serpent, while an Immortal Man by means of the Time puts an order on the watery chaos, and the elements of the Time can be associated with the members of the celestial church, since A. Pasquier has demonstrated that the celestial church was allegorised by the author of the treatise Eugnostus the Blessed by the waters above the firmament. ${ }^{57}$ This scholar noted that for the reason by which the multiplicity is collected in order to arrive to the unity, it is called "the church" ( $\left.\dot{x} \kappa \lambda \eta \sigma^{\prime} \alpha\right)$, after the supra-celestial church, since the author of the

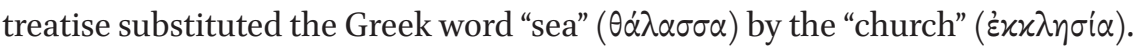
This substitution was inspired by the terms used in Gen. 1:10 for "gathering to-

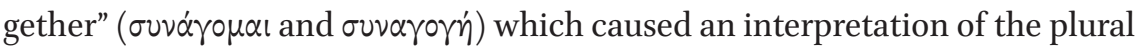
of Gen. 1:9 "And God said, Let the waters under the heaven be gathered together unto one place" in the sense that the church in this world is in the dissipation and multiplicity, while the celestial church is collected in "one unified multitude".

In this way, the celestial Church, correlating with the Plotinian conception of the unity represented by the eternity ( $\alpha i \omega v)$ as "a life that abides in the same" is put into order by the cross-Aion, measuring the universe as the Heavenly Man or an angel Metatron, which, as it seems, serves as a rational principle putting an order over the watery chaos, by way of baptizing the new members of the Church awakening from their deep sleep.

\footnotetext{
$55 \quad$ Ibid., p. 151.

56 Ibid., p. 151.

57 A. Pasquier, "L'allégorie du ciel et du firmament chez Origène et dans un traité gnostique de Nag Hammadi," in: Origeniana Sexta, actes du Coloquium Origenianum (1993), ed. by G. Dorival, A. Le Boulluec, Leuven, 1995, pp. 37-52.
} 

Body

The cosmic cross-Aion, measuring the universe as Logos, acquired an aspect of the measure and measurer of the Divine Body, and in this its aspect it was comprehended in some Christian cultural contexts as a suffering Logos. Primarily, it is worth noting that the cross of the vault decoration of the winter baths of Gaza or Antioch is associated with the idea of the sufferings $(\pi \dot{\alpha} \theta \eta)$.

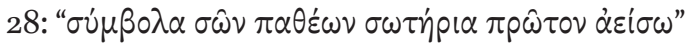

(First of all I will sing a song of praise to a delivering symbol of your sufferings)

This motive is taken by L. Renaut ${ }^{58}$ as an indication on Christian implications in the text of John of Gaza. However, the " $\pi \dot{\alpha} \theta \eta$ " of the cross on the vault of the bath can evoke the " $\pi \dot{\alpha} \theta \eta$ " of the Kosmos in Corpus Hermeticum XI, $15,{ }^{59}$ where the Aion is presented as the image of God, and the Kosmos is the image of Aion. Death is defined as the change, where the body is dissolved, while life proceeds into invisibility ( change, since every day some part of it becomes invisible ( $\gamma^{\prime}(\nu \varepsilon \sigma \theta \alpha$ l $\varepsilon \nu \tau \hat{\omega}$ $\dot{\alpha} \varphi \alpha \nu \varepsilon \hat{\imath})$, although does not dissolve, and this is characterised as the " $\pi \dot{\alpha} \theta \eta$ " of

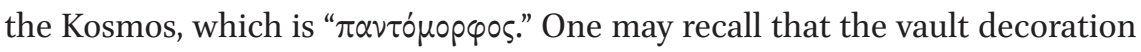
of the winter baths of Gaza or Antioch, according to the description of John of Gaza, was adorned by the image of the cross and the cosmic powers, where he

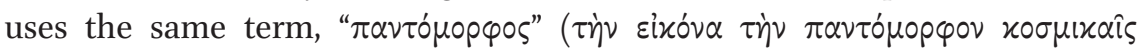

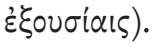

On the other hand, the " $\pi \dot{\alpha} \theta \eta$ " of the Kosmos can evoke the " $\pi \dot{\alpha} \theta \circ \varsigma^{\prime}$ " of the Logos in the apocryphal Acts of John (100-101), the text containing the discussion of the symbolism of the cross, where the Logos is represented as suffering and at the same time not suffering. As it was mentioned previously, P.J. Lalleman made an observation that "the Lord came down in order to assemble humans who listen to him and to resurrect them in the cross through his intervention. Salvation ends the chaotic pluriformity of human existence and brings rest in the chaos." ${ }^{\prime 60}$ Furthermore, this scholar has remarked interesting

\footnotetext{
58 Renaut, "La description d'une croix," p. 215.

59 Corpus Hermeticum, texte établi par A.D. Nock et traduit par A.-J. Festugière (Tome 1), Paris, 1991, p. 153.

6o Lalleman, The Acts of John, p. 198.
} 
features related to the use of the conception of the "Anthropos" in the Acts of John, beginning with his own, different translation of 101.14-16: "And so grasping man ( $\alpha \dot{v} \theta \omega \omega \pi \nu v)$, I say: first think of (the) Logos, then you shall think of (the) Lord, and thirdly of the man ( $\alpha \nu \theta \rho \omega \pi \circ v)$ and what he has suffered.' The first part of this phrase is hard to explain because of its brevity - several words may have been lost - and because of the many possible meanings of the verb

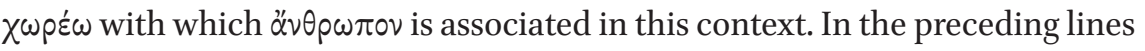
reference has been made to the Lord's revelation as the suffering Logos, which suggests that now the same Lord is designated as $\alpha \dot{\alpha} \theta \rho \omega \pi \circ v$, but this possibility cannot be more than a tentative conclusion." ${ }^{61}$

The verb $\chi \omega \rho^{\varepsilon} \omega$ was discussed in an article of Stroumsa which can shed light, probably, on its function in the Acts of John, since this scholar has indicated on the cases in the Patristic writings where this verb was used in a topological sense, ${ }^{62}$ and A. Orlov has demonstrated that the archangelic hypostasis of God "seems to play a formative role in creating such new identities of Enoch as the measure and the measurer of the divine body." 63 On the other hand, A.G. Gottstein came to a conclusion that the "physical understanding of image of God in rabbinic literature may be relevant to the development of the concept of the body of Christ when we realize that Christ is both image and body." ${ }^{\prime \prime}$ This scholar continued developing his argument suggesting that "as first-born Jesus restores the original zelem. The concept of image of God allows Paul to address Gentiles as well as Jews, for this image is not a natural body, but a body

$61 \quad$ Lalleman, The Acts of John, p. 198.

62 “... van Unnik refers to an interesting tradition reported by Irenaeus and possibly related by "the Presbyter" explicitly referred to elsewhere in the Adversus haereses: "Et bene qui dixit ipsum immensum Patrem in Filio mensuratum: mensura enim Partrem Filius, quo-

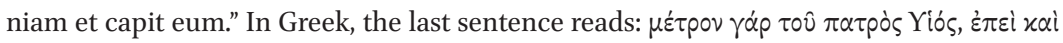

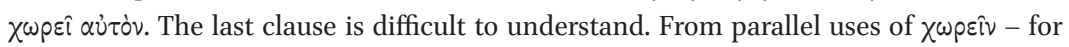
instance, in Adv. haer. 1.15.5, where Irenaeus describes the Father as he "who contains all things, and is not contained," it would appear that the clause reflects Irenaeus' gloss on the citation "the Son is the measure of the Father," and that the subject of $\chi \omega \rho \varepsilon \hat{~ i s ~ G o d . ~}$ The verb, moreover, should be understood in a topological sense." (G. Stroumsa, "Form(s) of God: Some Notes on Metatron and Christ," The Harvard Theological Review, 76 (1983), pp. 285-286).

63 A. ORLOv, " 'Without Measure and Without Analogy': The Tradition of the Divine Body in 2 (Slavonic) Enoch," in Scrinium 3: The Theophaneia School:Jewish Roots of Eastern Christian Mysticism, ed. by B. Lourí́ and A. ORLov, Санкт-Петербург, 2007, p. 237.

64 A.G. Gottstein, "The Body as Image of God in Rabbinic Literature," The Harvard Theological Review, 87 (1994), p. 193. 
of the elect, that is, the church." ${ }^{35}$ And in apocryphal Acts of John 97-98 the celestial church as the body of the elect is represented as a luminous cross.

And so I saw him suffer, and did not wait by his suffering, but fled to the Mount of Olives and wept at what had come to pass. And when he was hung (upon the Cross) on the Friday at the sixth hour of the day, there came a darkness over the whole earth. And my Lord stood in the middle of the cave and giving light to me said: "John, for the people below in Jerusalem I am being crucified and pierced with lances and reeds and given vinegar and gall to drink. But to you I am speaking, and listen to what I speak. I put into your mind to come up to this mountain so that you may hear what a disciple should learn from his teacher and a man from God. And when he had said this he showed me a Cross of Light ( $\sigma \tau \alpha u p o ̀ v ~ \varphi \omega \tau o ̀ s)$ brought to a fixed shape, and around the Cross a great crowd, which had no single form; and in it (the Cross) was one form and the same likeness. ${ }^{66}$

At this point one may recall that Lalleman interpreted the idea of incompleteness of the cross of light, which constituted the period of the suffering of the Logos as related to the Gnostic myth of the "the particles of the divine Logos that are spread over the world." However, the conception of the luminous cross as a suffering Logos can be explained in a different way, if to take into consideration other cultural context of the comprehension of this conception, which, in turn, can shed light on other aspects of the symbolism of the cosmic cross.

An image of the luminous cross from the Acts of John was familiar to Armenian readers, since, as K. Schäferdiek has noted, "a fifth-century Armenian translation based on a Greek original enjoyed a wide circulation, and found its way into Armenian biblical manuscripts; it has often been printed (survey in вно, No. 474), inter alia in the Armenian Bible edited by Jahannes Zohrab (Venice 1805, Appendix 27-29)."67

Taking into consideration this evidence, is seems plausibe to suppose that the conception of the luminous cross, probably, was known to the adepts of an

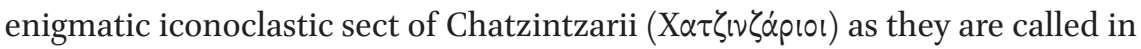
the Greek sources. As S. Der Nersessian has remarked, "According to Demetrius of Cyzica (Migne P. G. CXXVI, 881-8; the text is here wrongly attributed to Philip

\footnotetext{
65 Ibid., p. 194.

66 New Testament Apocrypha, ed. by W. Schneemelcher and R. Wilson, (Vol. 2), Westminster, 2003, p. 185 .

67 K. Schäferdiek, "The Acts of John: Introduction," in: New Testament Apocrypha, pp. 161-162.
} 
Solitarius), and to Nicephorus Callistus (P. G. CXLVII, 441-7) their name was derived from the Armenian word for cross: $\chi \dot{\alpha} \tau \zeta$ (khatch), because they worshipped the cross though rejecting all images ... but the Greek authors add that these men believed that there were two persons in Christ, one of whom had suffered on the cross, while the other had watched his sufferings." ${ }^{\prime 6}$

In fact, the ideas of these Chatzintzarii, namely, the duplication of the person of Christ, can have ancient Jewish-Christian roots. G. Stroumsa in his article "Christ's Laughter: Docetic Origins Reconsidered" adduced, among other texts, mentioned earlier Acts of John as representing a so-called docetic trend in the Christian thought where the suffering person is a substitute for Christ who secretly avoids the passions on the cross. ${ }^{69}$ In the same article Stroumsa suggested the origin of this motive of the laughter of Christ, a characteristic feature of this trend, as the Akedah of Isaac, whose name means "he will laugh". To this may be added that the binding of the lamb, as referring to the cross ("bind the lamb to the suffering") ${ }^{70}$ is evoked in the context of the martyrdom of Andrew, which is also known, among other versions, in an Armenian translation. As P. Heldt has noted, "the Armenian version of the sixth or seventh century is the most reliable source for Andrew's speech before his crucifixion, explaining that he and the cross, being of the same nature, are in the process of being unified, and that the cross reveals only partly the secret that it bears."71

In this way, one may suppose that the Christological conceptions found in the Apocryphal Acts of the Apostles, as it seems, can be interpreted in a way unforseen by their authors, and in an Armenian cultural context the cross of light from the Acts of John was, probably, comprehended as a symbol of the Cyrillian notion of the suffering Logos, which was interrelated with the Armenian tradition of the worship of the cross. As it was noted by W.H.C. Frend, "perhaps, the most decisive document in Armenian church history"72 was the Tome of the Patriarch of Constantinople Proclus, who "had belonged to the pro-Cyrilline party in Constantinople and his letter was a straightforward

68 S. Der Nersessian, "Image Worship in Armenia and Its Opponents," Armenian Quarterly, 1 (1946), p. 71, n. 16a.

69 G. Stroumsa, "Christ's Laughter: Docetic Origins Reconsidered," Journal of Early Christian Studies, 12 (2004), p. 273.

$70 \quad$ M. Pesthy, "Cross and Death in the Apocryphal Acts of the Apostles," in: The Apocryphal Acts of Peter, Louvain, 1998, p. 132.

$71 \quad$ P. Heldt, "New Testament Apocrypha," in: The Blackwell Companion to the New Testament, ed. D.E. Aune, Oxford, 2010, pp. 665-666.

72 W.H.C. Frend, The Rise of the Monophysite Movement: Chapters in the History of the Church in the Fifth and Sixth Centuries, Cambridge, 1972, p. 311. 
statement of Cyril's Christology,"73 and, as it was noted by J.M. Hallman, Cyril "insists that the sufferings of the Logos are truly his, but that he does not suffer in the divine nature," 74 while in the writings of St. Cyril of Alexandria the notion of the $x \dot{\varepsilon} v \omega \sigma$ เ is intricately connected with the notions of the glory ( $\delta \circ \xi_{\alpha} \alpha$ ) or the form ( $\left.\mu \circ \varphi \eta^{\prime}\right)$ (Dialogues on the Trinity vi):

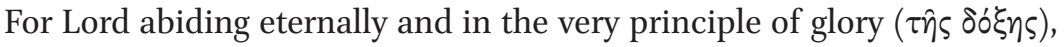
having been temporarily deprived of his glory by coming down to the humanly state, returns back upwards to the glory naturally inherent in Him, granting this glory through the economy of His flesh by the suffering ( $\mu \varepsilon \tau \dot{\alpha} \tau 0 \hat{v} \pi \alpha \theta \varepsilon \hat{\varepsilon} \nu)$ in the proportion fitting to his own self-emptying ( $\tau \hat{\eta}$

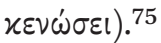

For He came down into the self-emptying (

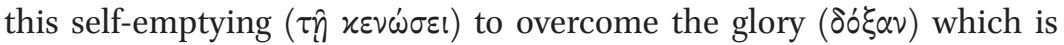
truly inherent in Him, but in order that those who are inferior and below, namely, we, would be able to spring up above through Him. ${ }^{76}$

For I think, one can say: if it is indeed a fact that the First-born has become man and by this revealed that He is the First-born, He properly deserves adoration for this; to the extent to which He is called in the extreme way self-emptied ( $\varkappa \varepsilon \varkappa \varepsilon \nu \omega \hat{\omega} \sigma \theta \alpha \mathrm{l})$, to this same extent He deserves the true hon-

Frend, The Rise of the Monophysite Movement, p. 311. Frend formulated the theological views of Proclus in the following way: "He (Proclus) pointed out how Christ as Word of God became truly man without passing through human experience $(\dot{\alpha} \pi \alpha \theta \hat{\omega} \varsigma)$ and took upon himself the form of a servant, but remaining as he was without change or addition. The Word was not united with a perfect man but 'became flesh by having descended into the nature itself' and voluntarily underwent human experiences. Any concept of a unity of opposites such as was implied by two distinct natures in Christ was absurd; the Word became man to repay the debt of man's sin and to save man from the power of death, and as Word incarnate suffered on the cross." (pp. 311-312).

J.M. Hallman, "The Seed of Fire: Divine Suffering in the Christology of Cyril of Alexandria and Nestorius of Constantiniple," Journal of Early Christian Studies, 5 (1997), p. 381.

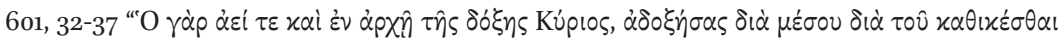

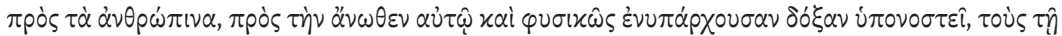

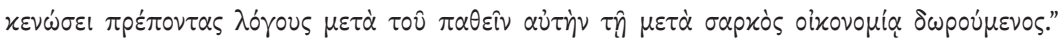
(Cyrille d'Alexandrie, Dialogues sur la Trinité, ed. G.M. de Durand (Sources chrétiennes, 246), Paris, 1978, p. 54)

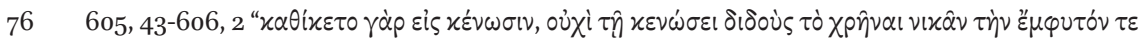

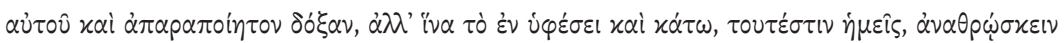
ił 


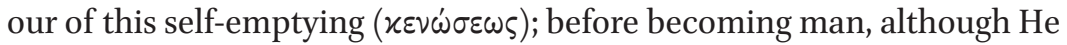
was in the form ( $\dot{\varepsilon} \nu \mu \rho \rho \varphi \hat{n})$ and likeness of the Father, He was not honoured by such a glory as when, as it is written, He leaped down into this humble nature, I mean the human nature. ${ }^{77}$

The connection between the notions of the "glory," or "form" with the notion of the "kenosis," probably, indicates on the fact that in this context the word "kenosis," can be comprehended as a technical term which, as it has been demonstrated by G. Stroumsa, is to be understood in the sense that the "incarnation implies for Christ giving up the greatness of his previous gigantic dimension."78 The "gigantic dimensions" of God's Glory were elaborated in the Jewish mystical tradition as the conception of the "Shi"ur qomah," which, as it was noted by A. Golitzin, "means literally "measure of the stature", that is, of the divine body of the kavod." This scholar observed that "in certain Jewish mystical texts, it is connected with, broadly, the visio gloriae and, specifically, with the ascent to the heavenly temple to see the enthroned divinity. There is good reason to believe that this tradition is very old. For example, the phrase, metron tēs hèlikias (that is, "of the fulness of Christ"), in Ephesians 4:13 is the exact Greek equivalent of the Hebrew shiur qomah, while another Pauline phrase, "body of his glory" (sōma tēs doxēs autou) in Philippians 3:21, to which the Christian is to become "conformed", is possibly in the same current, a notion which is supported by the perhaps contemporary, Jewish apocalypse of 2 or Slavonic Enoch." ${ }^{80}$

One may suppose that the Paulinian expression from Eph 3:18 “... may be able to comprehend with all saints what is the breadth, and length, and depth, and height" 81 can also fit into the same conception, and the reference to Eph

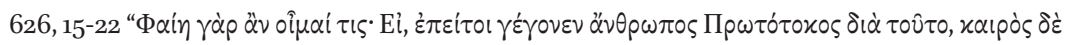

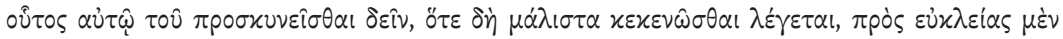

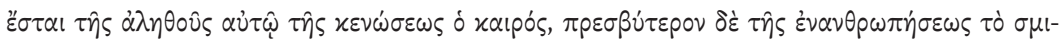

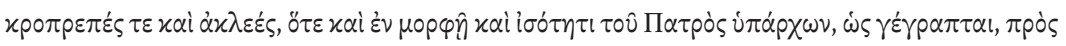

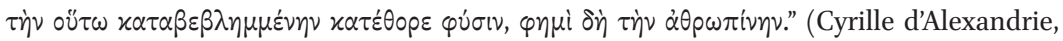
Dialogues sur la Trinité, p. 126)

78 Stroumsa, "Form(s) of God," pp. 169-188.

79 A. Golitzin, The Place of the Presence of God: Aphrahat of Persia's Portrait of the Christian Holy Man. An Essay in Honor of Archimandrite Aimilianos of the Monastery of Simonos Petras, Mount Athos. On-line: <http://www.mu.edu/maqom/aimilianos.html>

80 A. Golitzin, The Place of the Presence of God: Aphrahat of Persia's Portrait of the Christian Holy Man. An Essay in Honor of Archimandrite Aimilianos of the Monastery of Simonos Petras, Mount Athos. On-line: <http://www.mu.edu/maqom/aimilianos.html>.

81 For the survey of modern scholarly interpretations of this verse see H. Hoehner, Ephesians: An Exegetical Commentary, Grand Rapids, 2002, pp. 484-488. 
3:18 in combination with the Phil 2:8, the hymn, in which the technical term "kenosis," according to G. Stroumsa, probably, means that the "incarnation implies for Christ giving up the greatness of his previous gigantic dimension," ${ }^{82}$ occurs in the Great Catechism 32 by Gregory of Nyssa:

... it is from sight that the mighty Paul starts when he initiates the people of Ephesus in the mysteries, and imbues them through his instructions with the power of knowing what is that "depth and height and breadth and length." (Eph 3:18) In fact he designates each projection of the Cross by its proper appellation. The upper part he calls height, the lower depth, and the side extensions breadth and length; and in another passage he makes his thought still clearer to the Philippians, to whom be says, "that at the name of Jesus every knee should bow, of things in heaven, and things in earth, and things under the earth." (Phil 2:8) In that passage he includes in one appellation the centre and projecting arms, calling "things in earth" all that is in the middle between things in heaven and things under the earth. Such is the lesson we learn in regard to the mystery of the Cross. ${ }^{83}$

As it was demonstrated by Daniélou, Gregory of Nyssa in his interpretation of the cosmic cross depended on the interpretation of Irenaeus ${ }^{84}$ elaborated in the Demonstration of the Apostolic Preaching 34, the work which is extant now only in the translation into Armenian:

So then by the obedience wherewith He obeyed even unto death (Phil 2:8), hanging on the tree, He put away the old disobedience which was wrought in the tree. Now seeing that He is the Word of God Almighty, who in unseen wise in our midst is universally extended in all the world, and encompasses its length and breadth and height and depth (Eph 3:18) for by the Word of God the whole universe is ordered and disposed in it is crucified the Son of God, inscribed crosswise upon it all: for it is right that He being made visible, should set upon all things visible the sharing of His cross, that He might show His operation on visible things through a visible form. For He it is who illuminates the height, that is the heavens;

\footnotetext{
82 Stroumsa, "Form(s) of God," 169-188.

83 Tr. by W. Moore and H.A. Wilson, in: Selected Writings and Letters of Gregory, Bishop of Nyssa, Edinburgh, 1893. Reprinted on-line in: Gregory of Nyssa: Dogmatic Treatises, p. 687. <http://www.ccel.org/ccel/schaff/npnf205.html>

84 Daniélou, “La Symbolisme," pp. 33-34.
} 
and encompasses the deep which is beneath the earth; and stretches and spreads out the length from east to west; and steers across the breadth of north and south; summoning all that are scattered in every quarter to the knowledge of the Father. ${ }^{85}$

Thus, the texts under consideration reveal yet another aspect (besides those discovered by Daniélou) of the traditional, Jewish-Christian background of the interpretation of the cosmic cross in the Patristic literature in the sense of the Platonic Logos.

\section{The Cross as the Heavenly Self}

The image of the tree associated with the symbolism of the cross in this context may indicate in the direction of yet another development of the symbolical meaning of this instrument of the Passion of Christ, acquiring an aspect of the personal mystical experience. In a passage of the Ps.-Cyprian's De Montibus Sina et Sion, 13-14 the image of the tree is associated with the mirror, which corresponds to the theological conception contained in the Acts of John, noted by P.J. Lalleman, namely, that "the song and dance of Christ expresses his suffering which is also their suffering. In the song and dance, or rather in Christ himself as a mirror (95.45-46), men see their real identity." ${ }^{86}$

In this way, we find the Saviour himself saying through Solomon that He is an immaculate mirror of the Father, so that the Holy Spirit, the Son of God, saw Himself duplicated, the Father in the Son, and the Son in the Father, each of the two saw Himself in Himself, hence [the Son is] an immaculate mirror of the Father. For we who believe in Him, also see Christ in us as in a mirror, for He Himself instructs and reminds us in a letter of his disciple John to the people: "You see me in yourselves as one of you sees himself in water or in a mirror," and He confirmed the words

85 Tr. from the Armenian by J. Armitage Robinson, in: St. Irenaeus, The Demonstration, pp. 101-102. This translation differs in significant details from that which was adduced in the article of J. Daniélou, for which he, probably, used an older translation into German in Des

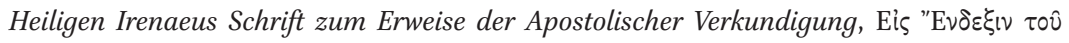
'A Deutsche übersetzt, von Lic. Dr Karapet Ter-Merkerttschian und Lic. Dr Erwand TerMinissiantz, mit einem Nachwort und Anmerkungen von Adolf Harnack, Leipzig, 1907, pp. 19-20.

86 Lalleman, The Acts of John, p. 193. 
which Solomon said about Him: "He is an immaculate mirror of the Father" (Wisd. 7:26).

Moreover, He also said about Himself as the true grape-vine, and about His Father as a gardener. Therefore, if Christ is the true grape-vine, certainly we also who believe in Him and are clothed in Him are a true grape-vine, which is in the vineyard of the Lord, and Christ is the keeper of the vineyard, according to Solomon who said: "They made me the keeper of the vineyard" (Song. 1:6). Thus, in the custom of this world we find a spiritual similitude, with a figurative meaning of the vineyard, which has its Lord and owner. In the proper time of the gathering of the grapes a servant-keeper on a high wooden pole fastened in the middle of the vineyard, and in this pole they make a square look-out post out of reed .... ${ }^{87}$

Daniélou has remarked that in this passage an author confused the words "speculum" (mirror) and "specula" (look-out post), ${ }^{88}$ however, this can be an intentional play of words rather than the confusion. J.E. Bruns has indicated on a possible connection between the "epistula Iohannis" and the Acts of John, 89 where Christ says: "I am a mirror to you who knows me" ("E $\sigma 0 \pi \tau \rho o ́ v ~ \varepsilon i \mu l ~ \sigma o l ~ \tau \hat{\omega}$ voov̂vi' $\mu \varepsilon$; Acts of John, 95). ${ }^{90}$ One may note also that the text of Ps.-Cyprian under consideration contains the reference to the Book of Wisdom 7:26 where

87 Ita inuenimus ipsum saluatorem per Salomonem speculum immaculatum patris esse dictum, eo quod sanctus spiritus Dei filius geminatum se uideat, pater in filio et filius in patre utrosque se in se uident: ideo speculus inmaculatus. nam et nos qui illi creadimus Christum in nobis tamquam in speculo uidemus ipso nos instruente et monente in epistula Iohannis discipuli sui ad populum: ita me in uobis uidete, quomodo quis uestrum se uidet in aquam aut in speculum, et confirmauit Salomonicum dictum de se dicentem: quis est speculus immaculatus patris. Vero etiam et uitem ueram se esse dixit, patrem suum agricolam. si egro Christus uitis est uera, utique constat quia et nos qui in illo credimus et ipsum induimus sumus uitis uera quae est in uinea dominica, et Christus custos uineae suae dicente Salomone: posuerunt me custodem in uin eam. inuenimus uero in conuersu huius mundi in similitudinem spiritalem figuraliter esse uineam habentem dominum et possessorem suum. uero tempore maturo prope dies uindemiarum ponunt in mediam uineam custodem puerum in alto ligno media uinea confixo et in eo ligno faciunt speculum quadratum de harundinibus quassatis ... (S. Thasci Caecili Cypriani Opera Omnia, ed. G. Hartel (CSEL III, Pars III), 1871, p.116,22 - p. 117,18).

88 J. Daniélou. Les origines du christianisme latin, Paris, 1991, p. 47.

89 J.E. Bruns, "Biblical Citations and the Agraphon in Pseudo-Cyprian's Liber de Montibus Sina et Sion," Vigiliae Christianae, 26 (1972), pp. 112-116.

9o Acta Johannis, 95, 12 (Acta Apostolorum Apocrypha, ed. by M. BonNET, Hildesheim, 1959, II, 1), p. 198. 


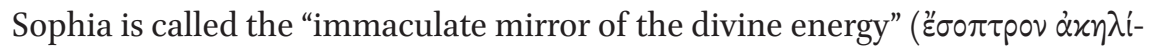

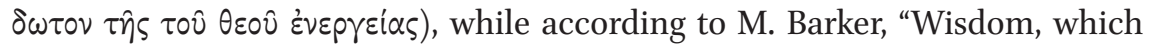
was the feminine aspect of the Lord, was also described as a tree of life (Prov. 3.18), and the early Palestinian Targum to Genesis said that the tree of life was the Torah whose fruits nourished the just." ${ }^{\text {11 }}$

In connection with the saying from the Acts of John, 95, elsewhere I have made an attempt to demonstrate that an ancient Jewish and Jewish-Christian interpretation of the experience of the encounter with the Glory in the Face of the Lord as the realization of the true celestial nature of a mystic was based on the ancient Semitic teaching about the origin of the world as the beginning of the communication between the "I" and the "Self" within the Supreme Principle, ${ }^{92}$ such as it is represented in Eugnostos the Blessed (NHC III), where God is he "who "sees himself within himself, like a mirror" (75.4-5)"93 or in the Apocryphon of John: "For it is he who looks at him[self] in his light which surrounds [him], namely the spring [of the] water of life. And it is he who gives to all the aeons and in every way, (and) who gazes upon his image which he sees in the spring of the Spirit. It is he who puts his desire in his water-light which is in the spring of the pure light-water which surrounds him." 94

One can encounter this imagery and vocabulary in the Plotinian description of the process of light filling the eye of the intellect in its ecstatic union with the One (VI, 7 [38] 36, 15-27):

It is there that one lets all study go; up to a point one has been led along and settled firmly in beauty and as far as this one thinks that in which one is, but is carried out of it by the surge of the wave of Intellect itself and lifted on high by a kind of swell and sees suddenly, not seeing how, but the vision fills his eyes with light and does not make him see something

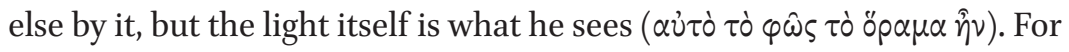
there is not in that Good something seen and its light, nor intellect and object of intellect, but a ray ( $\alpha \dot{\gamma} \gamma \dot{\eta})$ which generates these afterwards and lets them be beside it; but he himself is the ray which only generates Intellect ( $\alpha \dot{\gamma} \gamma \dot{\eta} \mu$ óvov $\gamma \varepsilon v \nu \omega \tilde{\omega} \alpha$ vov̂) and does not extinguish itself in the generation, but it itself abides, and that Intellect comes to be because this

\footnotetext{
91 M. Barker, The Gate of Heaven. The History and Symbolism of the Temple in Jerusalem, London, 1991, p. 95.

92 I. Kolbutova, "Face to Face and One Face Reflected in Many Mirrors," Scrinium, 9 (2013), pp. 207-228.

93 A.D. De Conick, Seek to See Him: Ascent and Vision Mysticism in the Gospel of Thomas, Leiden, 1996, p. 68.

Tr. by F. Wisse, in: The Nag Hammadi Library, p. 107.
} 
Good exists. For if this was not of the kind it is, that would not have come into existence. ${ }^{95}$

In his discussion of the mysticism in Plotinus J. Rist connected the two Plotinian thoughts, one of which is contained in the above quoted passage (VI, 7 [38] $36,15^{-27}$ ) and the second is V, 5 [32] 8, 4-5, which, according to Rist, "is similar - that beautiful section of the Enneads where Plotinus urges us not to 'pursue' the vision, but to await its arrival quietly and prepare oneself, 'just as the eye awaits the rising sun'" 96 Cannot this be that this is more than a metaphor and Plotinus, probably, intended to evoke an ancient Egyptian conception of the sole eye in the inert ocean Nun and the birth of Shu as a twilight anticipating the appearance of the sun?

As it was discussed previously, similar mythological imagery, namely, that "the birth of Shu means that light is dawning and this makes those who are in the doorway, probably, the doorway of the horizon, rejoice" 97 resembles the interpretation of the baptism by Gregory of Nyssa which, probably, can correspond to the ancient baptismal rituals and their interpretations. According to this Church Father, baptism means the unfoldment of our veil $(\kappa \alpha \tau \alpha \tau \dot{\varepsilon} \tau \alpha \sigma \mu \alpha)$ of the flesh, by the mortification of our earthly members, by which the door is open which allows the Logos enter the soul, about which J. Daniélou noted that the image of the veil $(\varkappa \alpha \tau \alpha \pi \dot{\varepsilon} \tau \alpha \sigma \mu \alpha)$ refers to the curtain of the temple concealing the Holy of Holies.

On the other hand, in the Christian iconography can be discerned other themes, related to the discussed previously images and ideas. Thus, in the Byzantine hymnography of the Cross, as it was demonstrated by B. Bucur, ${ }^{98}$ the cross in the Canon for the Third Sunday of the Lent serves as the image of the "footstool of God's throne," which corresponds to the Jewish tradition of the understanding of the ark in the holy of holies as the footstool of God's throne. The same idea, according to this scholar, is expressed "in the words of the Latin hymn, Regnavit a lingo Deus, the God of Israel rules from the Cross."99 This Hymn, namely, the "Vexilla Regis," contains also the strophe "Salue ara, salue victima/depassionis Gloria,/quaVitamortempertulit/etmorte uitam reddidit," (Hail, altar, hail, victim, with regard to the glory of your sufferings, by which

Tr. by A.H. Armstong in: Plotinus, Ennead VI with an English translation by A.H. Armstrong (Loeb Classical Library, 468), Cambridge, MA-London, 1988, p. 201.

96 J.M. Rist, Plotinus: the Road to Reality, Cambridge, 1967, pp. 224-225.

97 Englund, "The Eye of the Mind," p. 93.

98 B. Bucur, " "The Feet that Eve Heard in Paradise and Was Afraid": Observations on the Christology of Byzantine Hymns," Philosophy and Theology, 18 (2007), pp. 13-16. Ibid., p. 14 .

100 Venance Fotunat, Poèmes, Éd. M. Reydellet (Tome I, Livre II, vi), Paris, 1994, p. 58. 
Life endured death, and by your death gave back life), which seems to correspond verbally to the titluli in the so-called "anagogical window" of the twelfthcentury Latin author, abbot of St-Denis Suger: "Foederis ex arca Christi cruce sistitur ara; / Foederis maiori vult ibi vita mori" (On the Ark of the Covenant is established the alter with the Cross of Christ;/Here Life wishes to die under a greater covenant). ${ }^{101}$ The medallion is decorated with the iconographic type of the so-called "Gnadenstuhl", ${ }^{102}$ where a huge figure with a nimbus around the head encompasses the cross with a tiny image of Christ on it, and the whole construction is surrounded by the Living Creatures of the Ezekiel's vision. The cross is superimposed on the "Quadriga Aminadab" from 2 Sam 6:5, the cart with the Ark of the Covenant. ${ }^{103}$ The combination of the cross and the Ark as the "footstool of God's throne," as it seems, corresponds to the hymnographic tradition, referring to the conception of the "kenosis," which evokes Phil 2:8 with its theme of the "shrinking" of the great figure of divine glory which in Suger's window encompasses the cross, having evidently cosmic dimensions, to the human form of the "servant" on the cross.

The connection of Ezekiel's vision with the Ark of the Covenant in the Suger's iconography of the "Gnadenstuhl" is related to the interpretation of this prophetic vision, made by R. Elior, as the transformation of the ritual objects of the destroyed earthly Temple, where the winged Living Creatures correspond to the winged Cherubim covering the ark. ${ }^{104}$ The connection of the cross and the ark in the context of an early Christian development of the theological thought can be found in a Nag Hammadi treatise Gospel of Philip. As A.D. DeConick has noted, "the believers who "belong to the order of the priesthood" because they have prepared themselves sacramentally for entry into the Temple, will "go within the veil" led by Jesus "the High Priest" ... (85:3-5). The Ark of the Covenant is "their salvation" since they find themselves under "the wings of the Cross" ... (84:33-35). This statement seems to reflect the Jewish tradition of the mystic's entry into the Holy of the Holies and his enthronement between the winged cherubim which overlaid the lid of the Ark. Thus since they are seated under the wings of the Cross upon the kapporet it can be

101 Tr. by E. Panofsky, in: Abbot Suger, On the Abbey Church of St.-Denis and its Art Treasures, edited, translated, and annotated by E. Panofsky, Princeton, 1979, pp. 74, 14-15.

102 Concerning the term and the iconographic type see F. Boespflug and Y. Zaluska, "Le dogme trinitaire et l'essor de son iconographie en Occident de l'époque carolingienne au IV Concile du Latran (1215)," Cahiers de civilisation médiévale, 37 (1994),pp. 202-207.

103 K. Hoffmann, "Sugers 'Anagogishes Fenster' in St. Denis," Wallraf-Richarts-Jahrbuch, 30 (1968), pp. 65-69.

104 R. Elior, "The Priestly Nature of the Mystical Heritage in "Heykalot literature"," in Expérience et Écriture Mystiques dans les Religions du Livre, eds. Paul B. Fenton and Roland Goetschel, Leiden, 2000, pp. 48-51. 
understood that they have been enthroned and transformed."105 In conformity with this conception in the part entitled "and God rested on the seventh day" of the early fifteenth-century "Four-part icon" from the Cathedral of Annunciation of the Moscow Kremlin (early 15th c.) ${ }^{106}$ in an iconographic formula of the "Gnadenstuhl" the cross is represented as having wings.

5 Conclusion

The symbolism of the cross reveals a common Jewish-Christian background expressed by images, which may be found in the very broad geographical and chronological framework within the Christian world. The cross served as the measure and the measurer, putting order on the primordial chaos of the universe and the chaos of the human nature by the sacrament of baptism. The conception of the cross embraces the images and their theological meaning conveying all the story of the Creation, Fall, Redemption, and the Salvation, since in its manifold metamorphosis it has allusions to the concepts of the Primordial man, related to the Logos, the Tree of Life, the Serpent, the personification of the Church, with references to the themes of baptism and eucharist.

One may note that these images and conceptions correlate with the themes discussed by M. Barker concerning the ancient temple, especially the 'mercy seat' is (kapporeth), ${ }^{107}$ and it is interesting to note that, as it was observed by M. Barker, the imagery of the ark, referring to the temple, is related to the altar of a Christian church. ${ }^{108}$ The same theme, as it was observed by M. Barker, can be traced not only in the actual decoration of the church, but also in the Byzantine treatment of the symbolism of the liturgy and architecture: "Germanus of Constantinople (early eighth century) in his book On the Divine Liturgy presents the temple symbolism in great detail .... The holy table, the spiritual altar, corresponds to the kapporet over the ark, the cherub throne where the blood of the Lord was offered by the High Priest on the Day of Atonement."109

105 A.D. DeConick, "The True Mysteries: Sacramentalism in the Gospel of Philip," Vigiliae Christianae, 55 (2001), pp. 256-257.

106 I. Kachalova, N. Mayasova, L. Shchennikova, Blagoveshchenskij Sobor Moskovskogo Kremlya, Moscow, 1990, Pl. 178; 179.

107 Barker, The Gate of Heaven, pp. 139-140.

108 M. Barker, The Great High Priest: the Temple Roots of the Christian Liturgy, Edinburgh, 2003, p. 70.

109 Ibid., pp. 68-69. 
In fact, in the Historia mystagogica, attributed to Patriarch Germanus I, the symbolism of the cave is expressed in the following way:

The conch is after the manner of the cave of Bethlehem where Christ was born, and that of the Cave where He was buried as the Evangelist saith, that there was a cave "hewn out of the rock, and there laid they Jesus." (Mk. 15:46; Jn. 19:42) 110

On the other hand, in the apocryphal Acts of John 97-98, discussed in our article, the cross symbolism is also interrelated with the symbolism of the cave, and, as it was discussed previously, the cross in the Christian mental or depicted iconography, serves as the measure and the measurer both of the Divine Body and the universe. The connection of this meaning with the symbolism of the cave can be clarified by the corresponding themes within the framework of the Jewish mystical tradition. As it was discussed by Wesley Williams, "in rabbinic literature 'city' is also a metaphor for the human body and the use of the term viylon and its association with the lower heavens recalls the goat-hair curtains::lower-heaven::human skin nexus encountered above. This anthropomorphic reading is supposed by a comparison of Sifre Deutoronomy with $b$. B.Bat 58a:

R. Bana'ah used to mark out caves [where there were dead bodies]. When he came to Abraham, he found Eliezer the servant of Abraham standing at the entrance. He said to him: What is Abraham doing? He replied: He is sleeping in the arms of Sarah, and she is looking fondly at his head. He said: Go and tell him that Bana'ah is standing at the entrance: Said Abraham to him: Let him enter; it is well known that there is no passion in this world. So he went in, surveying the cave, and came out again. When he came to the cave of Adam, a voice came forth from heaven saying, 'Thou hast beholden the likeness of my likeness, my likeness itself thou mayest not behold.' 'But,' he said, 'I want to mark out the cave.' 'The measurement of the inner one is the same as that of the outer one' [came the answer] (Those who hold that there was one chamber above another [say that the answer was], 'The measurement of the lower one is the same as that of the upper one'... The beauty of R. Kahana was a reflection of [the beauty of Rab; the beauty of Rab was a reflection of] the beauty of R. Abbahu; the beauty of R. Abbahu was a reflection of the beauty of out father Jacob, and the beauty of Jacob was a reflection of the beauty of Adam.'

110 C. Mango, The Art of the Byzantine Empire, 312-1453: sources and documents, Toronto, 1993, p. 142. 
The point of this midrash is clearly the relationship between the upper Adam, God's very likeness, and the lower Adam, whose place is here taken by Abraham. Like the inquiring Israelites of Sifre Deutoronomy, R. Bana'ah seeks the "measure" of the (cave of the) Likeness on high, the upper Adam. And like those Israelites, his request is denied, but he is told to refer to the measure of the (cave of the) lower Adam (or "lower chamber"). While the measures agree, the end of the midrash contrasts the beauty of the upper Adam with its poor reflection, the lower Adam (viz Jacob)."111

This piece of evidence can shed light on the significance of the precise measures of the holy sites applied to the construction of Christian churches. As it was observed by R. Krautheimer, "measurements are several times referred to as having been brought from Jerusalem for the specific purpose of laying out a copy of the Anastasis or of the Tomb of Christ .... At Cambray a Holy Sepulchre was erected in 1063-64 "rotundo schemate in modum scilicet sepulchri quod est Jerosolimis. Unde et marmor superpositum sepulchro Cameracensi habet longitudinem 7 pedum quoniam et locus, ubi positum fuit corpus Domini eiusdem longitudinis existit." Sometimes a mere linear indication sufficed to give the measurements of the Tomb of the Lord: such is the case at Bebenhausen where as late as 1492 the sarcophagus of Christ was represented by three intersecting lines on the wall of the cloister, accompanied by inscriptions describing them as representing its length, depth and width."112 One may suppose that into this tradition fits the conception of the precise measures of the cross, corresponding to the size of Christ, which was indeed a real object in Hagia Sophia; it is mentioned by Constantine Pophyrogenitus in the Book of Ceremonies and, in the twelfth-century, by the pilgrim Anthony of Novgorod, "the famous cross - once in the Skeuophylakion of Hagia Sophia and used in the liturgy - which was exactly the size of Christ's body and contained the true relics of the Passion."113

111 W. Williams, THE SHADOW OF GOD. Speculations on the Body Divine in Jewish Esoteric Tradition. On-line <http://www.theblackgod.com/Shadow\%20of\%20God\%2oShort\%255 B1\%255D.pdf>

112 R. Krautheimer, "Introduction to an "Iconography of Mediaeval Architecture"," Journal of the Warburg and Courtauld Institutes, 5 (1942), p. 12.

113 H. Belting, "An Image and its Function in the Liturgy: the Man of Sorrows in Byzantium," DOP, 34 (1980-1981), p. 11. 